III. INTERPRETATION OF THE SOLAR X. U.V. OBSERVATIONS 


\title{
THE INTERPRETATION OF THE SUN'S XUV RADIATION
}

\author{
by C. W. Allew \\ (University of London Observatory, United Kingdom.)
}

Rfsumt. - On passe en revue nos connaissances sur l'ionosphère terrestre et l'atmosphère solaire en relation avec les observations récentes du rayonnement $X$ et $U V$ du Soleil.

On déduit aussi directement que possible des observations en XUV les principales carastéristiques de l'ionosphère et on les compare avec ce que l'on sait de la formation des couches $E$ et $F$. Il semble que les coefficients de recombinaison ionosphériques sont élevés et décroissent rapidement avec l'altitude. On trouve aussi que les rayonnements des ions élevés varie plus au cours du cycle solaire que celui des ions bas ; ceci entraîne quelques difficultés pour expliquer la constance du rapport des fréquences critiques des couches $E \dot{a} F$. Les rayons $X$ et $U V$ semblent contribuer ensemble à la formation de la couche $E$.

On a identifié environ 250 raies d'émission solaires $X$ et $U V$ provenant de 50 ions. Les mesures de flux fournissent des informations sur le nombre des ions correspondants dans l'atmosphère solaire. Chaque émission provient d'une région de température définie comprise entre 20000 et $2000000^{\circ} \mathrm{K}$, ce qui permet de déterminer (a) la quantité de matière solaire dans chaque gamme de températures, (b) les abondances chimiques, (c) les différences d'état physique entre l'atmosphère solaire normale, les centres actifs et les éruptions.

Les progrès de l'analyse sont actuellement arrêtés jusqu'à ce que le problème des coefficients de recombinaison diélectronique soit résolu. Une bonne distribution de la matière en fonction de sa température devrait prochainement être obtenue mais l'adaptation de ce résultat à des modèles de la chromosphère et de la couronne posera de nombreux problèmes.

ABSTRACT. - This paper reviews our understanding of (a) the earth's ionosphere, and (b) the solar atmosphere, in relation to the recent observations of solar $X U V$.

The expected ionospheric characteristics are derived as directly as possible from the $X U V$ observations and then compared with the well known $E$ and $F$ layer formation. Agreement does not come very naturally. There are indications of a high ionospheric recombination coefficient decreasing rather rapidly with height. It is found that radiations from the high ions have greater solar cycle variations than radiations from the low ions. This leads to some difficulty in explaining the constancy of the $E$ to $F$ critical frequency ratios. Both $U V$ and $X$-rays appear to contribute to the $E$ layer.

There are about 250 identified $X U V$ solar emission lines from about 50 ions. The flux measurements for each line gives information on the number of corresponding ions in the solar atmosphere. Each radiation comes from a region with a well specified temperature selected from the whole available range $20000^{\circ}$ to $20000000^{\circ} \mathrm{K}$. This makes it possible to derive, (a) the amount of solar material in each temperature range, (b) the chemical abundances, and (c) the physical differences between normal solar atmosphere, centres of activity, and flares. The analysis is held up at the present moment until the problem of the dielectronic recombination coefficient is cleared. In due course a good distribution of matter with temperature should be available but the fitting of such results to chromospheric and coronal models provides many problems.

Резюме. - Просмотрены наши знания о земной ионосфере и солнечной атмосфере в связи с недавними наблюдениями X и UV Солнца.

Выведены, по возможности самым прямым путем, из наблюдей в XUV главные характеристики ионосферы и сравнены с тем, что нам известно об образовании слоев $\mathbf{E}$ и $\mathbf{F}$.

По-видимому ионосферные коэффициенты рекомбинации высоки и быстро убывают с высотой. Найдено также, что излучения высоких ионов изменяются во время солнечного цикла больше чем излучение низких ионов ; это влечет некоторые затруднения, чтобы объяснить постоянств отношения критических частот слоев $\mathbf{E}$ и $\mathbf{F}$. Эти лучи $\mathrm{X}$ и UV как будто способствуют образованию слоя $\mathbf{E}$.

Были отождествлены около 250 солнечных эмиссионных линий X и UV mpоисходящих от 50 ионов. Эти измерения потока дают сведения о числе соответствующих ионов в солчечной атмосфере. Каждая эмиссия происходит из области определенной температуры заключенной между 20.000 и 2.000.000 ко, что позволяет определить : a) количество солнечного вещества в 
каждом диапазоне температур; b) химические обилия; c) различния физического состояния между нормальной солнечной атмосферой, аштивными центрами и вспышками.

Продвижение анализа в настоящее время приостановлено до тех пор, пока проблема коэффициентов диэлектронной рекомбинации не будет разрешена. Хорошее распределение вещества в зависимости от его температуры должно бы быть получено в ближайшее время, но применение этого результата к моделям хромосферы и короны поставит многочисленные задачи.

The full text of this review has been published in Space Science Revieu's, Vol. 4. no 1, Feb. 1965.

\section{Discussion}

C. Pecker-Wimel. - The importance of the radiation field in the resonance lines of ions formed in the chromosphere cannot be underestimated $a$ priori. The optical depth in the resonance line of C III formed in the same region of the solar atmosphere as the He I and $\mathrm{He}$ II lines is of the order of $10^{3}$.

C. W. Allen. - The large optical depths are well known but the analyses of POTTASCH and others show that the greater part of the scattered radiation will emerge from the emitting layer. In any case, because there are many lines with much smaller optical depths, there will be plenty of opportunity to check whether results are consistent or whether some further correction is necessary.

C. Phoker-WrmmL. - It is dangerous to treat the 150 emission lines observed in the solar U. V. as coming always from a two-level atom. This is not the case mainly in the chromosphere where many lines of the same ion must be treated at the same time in a multilevel atom. F. H. Venables. - On the formation of the E- region, we, at Slovar, have observed 44-60 A X-ray fluxes, using the N. R. L. solar radiation satellite. We have found a rather poor correlation with E-region electron densities, indicating that X-rays of these wavelengths are not of primary importance in the production of E-region ionization.

L. GoldBerg. - The inclusion of dielectronic recombination will substantially increase the width of the emitting region, and this may require revision of the theory. It is interesting to recall that TOUSEY's observations seem to show that the width of $\mathrm{O}$ VI emission is about $50000 \mathrm{~km}$. 